\title{
Komunikasi Interpersonal Keluarga sebagai Penunjang Kesehatan Mental Mahasiswa Rantau Asal Papua-Papua Barat
}

\section{Family Interpersonal Communication as Supporting Mental Health for Overseas Students from Papua-Papua Barat}

\author{
Hana Aviela Fedria Wowor* \& K.Y.S. Putri \\ Program Studi Ilmu Komunikasi, Fakultas Ilmu Sosial, Universitas Negeri Jakarta, Indonesia \\ Diterima: 03 Juli 2021; Disetujui: 15 Desember 2021; Dipublish: 1 Januari 2022

\begin{abstract}
Abstrak
Pada penelitian ini, peneliti bertujuan untuk mengetahui bagaimana komunikasi interpersonal dalam keluarga dapat menunjang kesehatan mental seseorang, khususnya mahasiswa perantauan. Penelitian ini menggunakan metode kualitatif dengan pendekatan fenomenologi, yang mana berfokus untuk menceritakan fenomena peran komunikasi keluarga terhadap mental mahasiswa, yang dialami langsung oleh para mahasiswa perantauan asal Papua-Papua Barat. Hasil dari penelitian ini memperlihatkan bahwa komunikasi sangat berperan dalam menunjang kesehatan mental seseorang, terkhusus mahasiswa perantauan yang kini harus berkuliah di situasi pandemi. Komunikasi yang menunjang ini berupa komunikasi yang terbuka dan mau mendengar. Pada masa pandemic ini, beberapa mahasiswa memilih pulang ke kampung halaman, tetapi ada pula yang harus menetap di perantauan karena suatu kondisi. Masing-masing mahasiswa menceritakan pengalaman yang berbeda, tetapi kurang lebih memiliki kesamaan, yaitu merasa tertekan atau stress dengan perkuliahan. Melalui komunikasi, mahasiswa cenderung merasa beban mereka berkurang. Respon orang tua juga membangun semangat dalam diri mahasiswa dan memberi kekuatan, yang mana hal ini mengurangi stress dan membantu kesehatan mental mahasiswa. Kesediaan orang tua untuk mendengar cerita dan memberikan kata-kata positif ternyata memberi perasaan nyaman dan legah bagi para mahasiswa.
\end{abstract}

Kata Kunci: Komunikasi Interpersonal; Kesehatan Mental; Keluarga; Mahasiswa Rantau

\begin{abstract}
In this study, the researcher aims to find out how interpersonal communication in the family can support a person's mental health, especially overseas students. This study uses a qualitative method with a phenomenological approach, which focuses on telling the phenomenon of the role of family communication on student mentality, which is experienced directly by overseas students from Papua-West Papua. The results of this study show that communication plays a very important role in supporting one's mental health, especially overseas students who now have to study in a pandemic situation. Communication that supports this in the form of open communication and willing to listen. During this pandemic, some students chose to return to their hometowns, but some had to stay overseas due to certain conditions. Each student told a different experience, but more or less had something in common, namely feeling pressured or stressed with lectures. Through communication, students tend to feel their burden is reduced. Parental responses also build enthusiasm in students and provide strength, which reduces stress and helps students' mental health. The willingness of parents to hear stories and give positive words turned out to give students a feeling of comfort and relief.
\end{abstract}

Keywords: Interpersonal Communication; Mental Health; Family; Overseas Students

How to Cite: Wowor, H.A.F., \& Putri, K.Y.S., (2022). Komunikasi Interpersonal Keluarga sebagai Penunjang Kesehatan Mental Mahasiswa Rantau Asal Papua-Papua Barat. PERSPEKTIF, 11 (1): $205-213$.

*Corresponding author:

E-mail:wowor@gmail.com

ISSN 2085-0328 (Print)

ISSN 2541-5913 (online) 


\section{PENDAHULUAN}

Situasi pandemi Covid-19 mengharuskan masyarakat untuk menjaga jarak dan menghindari keramaian. Oleh karena itu, diterapkan Work from Home (WFH) sampai proses belajar jarak jauh, di mana semua aktivitas, baik bekerja ataupun belajar dilakukan dari rumah masing-masing dengan perantara jaringan internet dan media online lainnya. Keadaan ini menimbulkan dampak positif dan negatif. Salah satu dampaknya adalah tekanan pekerjaan atau tugas yang lebih padat dibandingkan saat offline.

Tidak terkecuali bagi mahasiswa yang kerap kali disibukkan dengan tugas kuliah yang menumpuk, Hasil penelitian (Lubis et al., 2021) menuliskan kebanyakan mahasiswa mengalami stress kategori sedang. Stress tersebut berupa tekanan dalam mengikuti perkuliahan online di masa pandemi, seperti perasaan tidak nyaman, rasa tegang, dan adanya perubahan perilaku. Berdasarkan penelitian Yusof dan Rahim (2020) stress bisa terjadi karena materi pelajaran yang banyak, kurangnya timbal balik dari dosen, cara mengajar, dan tugas yang banyak. Mahasiswa juga menjadi tertekan karena keharusan untuk menguasai materi dan keterampilan pada waktu yang singkat (Lubis et al., 2021).

Sebagai tambahan, hasil penelitian artikel “Gangguan Kesehatan Mental yang Disebabkan Oleh Pendidikan Jarak Jauh Terhadap Mahasiswa Selama Pandemi Covid-19" menjelaskan bahwa adanya pembelajaran jarak jauh menyebabkan mahasiswa mengalami gangguan kesehatan mental, karena factor pembatasan aktivitas di luar rumah, meningkatnya penggunakan telepon genggam, serta kekuatan jaringan atau sinyal yang terkadang kurang mendukung proses belajar (Bonaria, 2021). Bagi mahasiswa perantau asal Papua-Papua Barat, tekanan yang dirasakan pun tidak jauh berbeda.

Masalah stress akademik atau tekanan dalam perkuliahan berkaitan dengan kesehatan mental mahasiswa. Dalam penelitian "Representasi Kesehatan Mental Siswa pada Masa Pandemic Covid-19" ditarik kesimpulan bahwa ada dua situasi kesehatan mental yang dialami siswa ketika masa pandemi covid-19. Pertama, psychological distress, yaitu rentang kesehatan mental berada pada posisi negatif. Mengalami perasaan jenuh, capek, tidak nyaman, sulit konsentrasi, mudah merasa cemas, perasaan tidak berharga, tertekan, tidak mampu melakukan kegiatan yang bersifat positif dan pesimis. Kedua, psychological wellbeing, kondisi di mana seseorang dalam kesehatan mental yang positif atau baik. Orang tersebut mampu menerima kondisi karena memiliki teman senasib, mampu menyemangati diri sendiri karena orang-orang baik yang ada di sekitarnya, seta menikmati dan berpikiran positif, serta dapat menyalurkan hobi (Lestari \& Risqi, 2021).

Pemahaman tentang kesehatan mental di Indonesia terbilang masih kurang, sehingga tidak sedikit remaja yang nekat melakukan tindakan melukai diri sendiri, hingga mengakhiri hidup. Dilansir oleh Redaksi Sehat Negeriku dalam website sehatnegeriku.kemkes.go.id, bahwa masyarakat belum menganggap masalah kesahatan jiwa sebagai sesuatu yang perlu diperhatikan. Pada hasil Riskesdas pada tahun 2018, remaja berumur lebih dari 15 tahun sebanyak 9,8\% mengalami gangguan mental (ROKOM, 2019). Berdasarkan data terbaru yang dilansir pada laman unicef.org, banyak anak remaja berusia 10-19 tahun mengalami gangguan mental (UNICEF, 2021).

Masalah kesehatan mental bukan hanya suatu keadaan di mana orang tersebut dinyatakan mengalami gangguan mental, tetapi lebih dari itu. Kesehatan mental termasuk cara berpikir yang jernih, pengendalian emosi, serta bagimana seseorang bersosialisasi dengan orang-orang seusianya (Saskara \& Ulio, 2020). Kesehatan mental dapat dilihat dari faktor internal, keluarga, serta lingkungan. Faktor keluarga berupa pola asuh, seperti komunikasi antara orang tua dan anak, dan seberapa dekat anak dengan orang tuanya (Djayadin \& Munastiwi, 2020).

Komunikasi adalah proses menyampaikan pesan dari seorang komunikator kepada komunikan melalui sebuah tahapan, media, sehingga pesan tersebut menghasilkan pengaruh atau dampak. Komunikasi mempunyai banyak fungsi, sebagai pembentukan konsep diri, menyatakan eksistensi diri, membentuk hubungan, menyampaikan perasaan, mengajar, menghibur, dan lain-lain (Tatang, 2016).

Komunikasi merupakan hal yang penting, sebuah kebutuhan manusia karena manusia adalah makhluk sosial yang selalu perlu berinteraksi, berbicara dengan orang lain dan 
membangun hubungan. Oleh karena itu, komunikasi juga penting dalam hal psikologis. Kecenderungan menutup diri dan memilih tidak mengkomunikasikan perasaan dapat menyebabkan seseorang mengalami tekanan, yang mana berkaitan juga dengan kesehatan mental. Dalam artikel "Komunikasi Interpersonal Keluarga Kristen Memasuki Era 4.0" menuliskan bahwa kualitas komunikasi atau hubungan seseorang bermanfaat unutk mencapai kesehatan mental seseorang. Kualitas komunikasi dan hubungan yang terbentuk ini khususnya mereka memiliki signifikansi dalam hidup orang yang terlibat dalam komunikasi dan hubungan tersebut (Sampe et al., 2019).

Orang tua adalah sosok terdekat untuk seorang anak. Sosok yang memiliki signifikansi dalam hidup seorang anak. Keduanya secara timbal balik perlu menyampaikan apa yang ada dalam pikiran dan perasaan mereka, sebagaimana yang diungkapkan oleh Joseph A. Devito, komunikasi interpersonal merupakan proses mengirim dan menerima pesan-pesan antara dua orang atau suatu kelompok kecil dengan beberapa umpan balik. Prosesnya terjadi ketika komunikator sebagai pengirim pesan menyampaikan pesan berupa verbal atau nonverbal (Tatang, 2016).

Komunikasi antara orang tua dan anaknya memiliki banyak dampak, seperti terhadap perkembangan emosi anak, pembentukan karakter dan sikap anak, menanggulangi kenakalan anak, meningkatkan minat belajar, hingga keberhasilan seorang anak. Selain itu, komunikasi orang tua dan anak juga berpengaruh terhadap kesehatan mental anak. Bentuk komunikasi seperti dukungan pada pendapat, ide atau pernyataan mampu menciptakan motivasi bagi pihak terkait dan memberikan dampak positif seperti perasaan semangat untuk mencapai suatu tujuan atau untuk mengerjakan suatu hal (Koraag et al., 2021).

Dalam penelitian peran keluarga dalam membentuk kesehatan mental remaja di kelurahan Yosorejo 21 A Metro Timur oleh Ayu Cahyanti menunjukkan bahwa banyak orang tua tidak menyadari bahwa komunikasi antara mereka dan anak berperan dalam kesehatan mental anak. Dijelaskan bahwa orang tua sebaiknya menjadi teman, memberi dorongan motivasi, mengeksplor bakat remaja, dan dukungan orang tua dalah hal yang penting untuk seorang remaja. Penelitian ini memperlihatkan bahwa banyak orang tua tidak menganggap bahwa kehadiran mereka penting bagi anak remaja mereka (Cahyanti, 2020).

Penelitian mengenai komunikasi orang tua dan tingkat stres mahasiswa perantauan pada larangan mudik (Nuzuli, 2020) menunjukkan bahwa komunikasi dengan orang tua merupakan salah satu hal penting yang dapat mengurangi tingkat stress mahasiswa rantau, khususnya mahasiswa Universitas Amikom yang tidak dapat mudik. Hasil uji regresi linear sederhana pada penelitian tersebut menunjukkan makin tinggi intensitas komunikasi dengan orang tua, tinkgat stres akan semakin rendah. Hal tersebut menunjukkan bahwa komunikasi dengan orang tua berperan atau menjadi salah satu hal dalam mengurangi stress atau tekanan pada mahasiswa.

Penelitian lainnya mengenai pola komunikasi keluarga terhadap kesehatan mental anak di tengah pandemi Covid-19 (Djayadin \& Munastiwi, 2020) menunjukkan bahwa penerapan komunikasi orang tua dan anak dalam keluarga berdampak besar pada kesehatan mental anak. Penelitian yang dilakukan pada keluarga Sulawesi ini memperlihatkan bahwa nilai-nilai positif yang ditanamkan pada anak akan memberi pengaruh positif untuk membentuk dan dalam perkembangan mental anak. Sistem nilai yang dimaksud berhubungan dengan kualitas emosi, seperti niali tata krama, sifat sabar dalam menyelesaikan persoalan, dan sikap toleransi, empati dan bersahabat dengan lingkungan. Pribadi anak yang cerdas intelektualnya dan emosionalnya akan menjadi dasar kesehatan mental anak. Hal tersebut dimulai dari penerapan pola komunikasi yang tepat dalam keluarga, karena anak tetap membutuhkan sosok orang tua yang bisa menjadi tempat berbagi cerita di berbagai situasi.

Penelitian yang berjudul "Emotionfocused Coping sebagai Strategi Koping Mahasiswa selama Pembelajaran Daring di masa Pandemi" yang dilakukan pada mahasiswa di NTT, menjelaskan beberapa bentuk emotion focused coping, yaitu berupa strategi untuk memanajemen tekanan yang dirasa. Beberapa hal tersebut seperti melakukan kegiatan spiritual seperti berdoa, berpikir positif, melakukan hobi atau minat untuk mengalihkan pikiran negatif, serta 
dukungan dari teman atau keluarga. Dukungan dari teman atau keluarga ini berupa kesediaan teman, keluarga, atau orang terdekat untuk mendengar cerita dari mahasiswa di NTT (Kiling et al., 2021).

Pada salah satu penelitian terdahulu oleh Effiati Juliana Hasibuan (2011) mengenai Peranan Komunikasi dalam Keluarga Terhadap Pembentukan Jati Diri Remaja, membahas bahwa komunikasi yang efektif akan berdampak pada pengertian, rasa senang, membangun hubungan baik, tindakan, serta memberi pengaruh pada sikap seseorang (Hasibuan, 2011). Pada situasi pandemi saat ini, kebanyakan mahasiswa rantau balik ke kampung halaman dan tinggal bersama keluarga, dibanding menetap di perantauan. Tetapi, untuk beberapa kondisi, ada mahasiswa rantau yang tidak bisa balik ke kampung halaman atau tinggal bersama orang tua. Melihat komunikasi ataupun kehadiran orang tua itu penting bagi kesehatan mental seorang anak, peneliti bertujuan untuk melihat bagaimana komunikasi orang tua dan mahasiswa berdampak pada kesehatan mental mahasiswa perantau asal Papua-Papua Barat.

\section{METODE PENELITIAN}

Penelitian ini menggunakan penelitian kualitatif fenomenologi, yaitu sebuah desain penelitian yang berasal dari filosofi dan psikologi. Peneliti akan mendeskripsikan pengalaman kehidupan seorang individu mengenai suatu fenomena sebagaimana yang dideskripsikan oleh informan (Creswell \& Creswell, 2018).

Data untuk mendukung penelitian didapat dari dokumen, berupa artikel penelitian sebelumnya dan beberapa buku sebagai referensi, serta melalui wawancara. Wawancara dilakukan pada sepuluh orang informan, dengan teknik penarikan sampel purposive sampling. Berdasarkan teknik tersebut, peneliti hanya memilih informan berdasarkan kriteria tertentu, yaitu mahasiswa aktif asal Papua dan/atau Papua Barat yang merantau di luar daerah asal.

Pengumpulan data berupa artikel dilakukan secara daring, yaitu melakukan pencarian pada google scholar mengenai artikel terkait fokus penelitian. Untuk pengumpulan data melalui wawancara dilakukan juga secara daring. Peneliti menghubungi beberapa kenalan dan meminta bantuan untuk menyebarkan kuesioner kepada beberapa orang dengan kriteria seperti yang dijelaskan di atas. Peneliti hanya melakukan wawancara pada informan yang merupakan mahasiswa, guna melihat fenomena dan pentingnya komunikasi dengan orang tua dari sudut pandang mahasiswa itu sendiri.

Situasi pandemi saat ini tidak memungkinkan adanya wawancara secara langsung, sehingga jika ada pertanyaan tambahan, peneliti akan menghubungi informan terkait melalui media sosial. Selanjutnya, sesuai dengan metode penelitian yang digunakan, yaitu fenomenologi. Peneliti mengolah kembali data yang diterima kemudian mendeskripsikannnya sesuai dengan pengalaman yang dijelaskan oleh informan, serta mengaitkan dengan beberapa teori yang telah dipaparkan pada bagian pendahuluan.

\section{HASIL DAN PEMBAHASAN}

Wawancara dilakukan dengan jumlah 10 orang mahasiswa perantau yang berasal dari Papua dan Papua Barat. Informan berusia 1920 tahun rata-rata sedang berkuliah semester 2 sampai semester 4. Pada wawancara yang dilakukan, masing-masing informan memberikan jawaban yang tentunya beragam. Awal-awal perkuliahan para informan mengaku merasa tertutup, malu untuk berbicara, susah karena jauh dari orang tua, tidak terbiasa dengan lingkungan baru atau susah beradaptasi, culture shock, canggung dan bingung. Walaupun demikian, ada pula yang merasa senang dan semangat di awal, kemudian merasa kaget dan homesick. "Awalnya sih lumayan susah karna jauh dari orang tua, terus tidak terbiasa dengan tempat baru dan teman-teman baru. Pokoknya waktu awal-awal tu lumayan susah lah, apalagi kalo jauh dari rumah." - Y.S.W

"Untuk kondisi awal perkuliahan sebenarnya untuk saya ada 2 sisi yang berbeda. Pertama yang pasti senang karena kebanyakan orang ingin melanjutkan pendidikannya di tempat atau kota yang berbeda yang sudah sebelumnya diinginkan atau diimpikan. Untuk sisi yang kedua ini bisa dibilang cenderung sedih karena jauh dari keluarga terutama orang tua. Waktu awal perkuliahan rasanya sangat berbeda sekali dengan masa sekolah. Banyak sekali hal yang harus bisa kita adaptasi dan terbiasa dengan lingkungan sekitar. Pada awal semester 1 perkuliahan, saya sudah 
menemukan beberapa teman dekat dari berbagai kota yang berbeda. Ya bisa dibilang menutupi sedikit rasa homesick karna bisa kumpul bareng teman-teman, Tetapi setiap malam pasti rasa homesick selalu ada dan tidak heran beberapa kali sempat sedih dan ingin kembali ke kota asal. Dan perasaan homesick itu terjadi hampir 1 semester awal perkuliahan". -M.I.T

Dua informan di atas mewakili pernyataan 10 informan yang lain. Ada yang merasa susah karena tidak terbiasa dengan lingkungan yang baru juga teman yang baru. Perasaan jauh dari rumah membuat perasaan yang tidak nyaman. Informan yang lain menceritakan perasaan yang beragam, senang dan sedih. Satu sisi merasa senang dengan kesempatan baru untuk berkuliah di luar kota, sedangkan sisi lain harus menghadapi suasana baru tanpa didampingi orang tua, terlebih situasi perkuliahan yang benar-benar berbeda dengan suasana SMA.

Saat ditanya perubahan situasi dari awal kuliah sampai saat ini, termasuk di saat pandemic, kesepuluh informan memiliki jawaban yang beragam. Sebagian besar informan sudah bisa beradaptasi dengan lingkungan baru dan perkuliahan mereka, tetapi di satu sisi karena adanya pandemi, mereka mengalami situasi baru yaitu perkuliahan online. Beberapa dari para informan ada yang pulang ke kampung halaman dan tinggal dengan keluarga. Sebagiannya lagi ternyata tetap tinggal di kota rantauan. Situasi pandemi ini memberi kondisi baru juga bagi para anak rantau, baik yang pulang ke kampung halaman maupun yang tetap berada di kota rantau.

"Dalam masa pandemi ini, saya lebih banyak menghabiskan waktu di kost dengan mengikuti kelas online dan mematuhi protokol kesehatan yang telah ditetapkan oleh pemerintah." - N.K.S

"Kalo sekarang semenjak ada temanteman baru, sa su bisa berpikir bahwa kuliah di rantau itu tra susah seperti yang tong bayangkan. Di saat pandemi begini walaupun bertemu hanya lewat virtual saja sa cukup senanglah karna masih bisa baku lihat lewat zoom dan aplikasi meeting lainnya." - Y.S.W

"Tentunya jauh berbeda, apalagi kuliah diadakan secara online sehingga saya kembali ke daerah asal saya. Hal ini tentunya ada sisi baiknya bagi saya, karena saya sangat senang ketika dapat kembali bertemu dengan keluarga dan kerabat, akan tetapi dalam beberapa situasi perkuliahan saya mengalami hambatan karena faktor jaringan yang tidak stabil.“ - M.P.K.W

"Kalau untuk sekarang susah yaa.. Karna kuliahnya harus menggunakan Zoom Googlemeet. Untuk bisa kuliah secara online di situasi pendemi saat ini kadang banyak kendalanya, seperti jaringan atau kuotanya dan kalau pas awal-awal kan enak, bisa langsung berinteraksi dengan dosen dan teman-teman juga, jadi tidak enaknya itu di situasi pendemi saat ini sih". -B.M.C.N

Berdasarkan beberapa jawaban di atas, informan sudah merasa nyaman dengan tempat kuliah yang baru. Tetapi, situasi pandemi karena Covid-19 memberi perubahan yang terasa, khususnya bagi yang memilih balik ke kampung halaman. Mereka yang memilih balik ke kampung halaman dapat menikmati kebersamaan dengan keluarga. Kesulitan yang terasa adalah kondisi perkuliahan yang dilakukan secara online seringkali terhambat oleh sinyal atau jaringan internet dan kuota internet. Walaupun begitu ada informan yang menyatakan kuliah virtual cukup untuk saling berkomunikasi dengan teman-teman perkuliahan.

Selain kesulitan sinyal yang telah disebutkan di atas, serta keuntungannya bisa berkumpul lagi dengan keluarga, ada situasi lain, yaitu perbedaan jam, jarak yang jauh, dan pemahaman materi. Informan berikut menyatakan perbedaan waktu dua jam antara kota rantau tempat berkuliah, yaitu Waktu Indonesia Barat (WIB) dan kota asal yang berzona Waktu Indonesia Timur (WIT) memberinya keuntungan, tetapi jarak Papua Barat - tepatnya Manokwari, memberi kesulitan dalam praktikum.

"Untuk kondisi saya sekarang yang pasti senang bisa kembali ke rumah dan berkumpul bersama keluarga, sebenarnya kondisi saat ini sedikit menguntungkan untuk saya karena kalau dilihat dari sisi perkuliahan untuk jadwal kuliah sangat berbeda ketika saya berada di Malang, seperti misal jadwal perkuliahan pagi dilaksanakan jam 07.00 WIB, karena perbedaan waktu 2 jam antara Malang dan Manokwari, sehingga membuat saya tidak harus bangun kepagian untuk kuliah di mana bisa saja telat untuk mengikuti perkuliahan. Tetapi di sisi lain cukup merugikan juga apalagi untuk saya yang 
kuliah dengan jurusan Teknik Sipil, harus menunda atau membatalkan beberapa praktikum yang semestinya wajib di laksanakan tetapi karena kondisi sekarang seperti ini maka seluruh praktikum ditiadakan. Melaksanakan perkuliahan dengan 2 semester saja dan sisa dari itu dilaksanakan secara online sedangkan praktikum di jurusan Teknik Sipil Universitas Negeri Malang di jadwalkan pada semester 3, dimana semester 3 hingga semester 4 sekarang ini banyak mata kuliah praktikum yang harusnya dilaksanakan. Sehingga membuat saya dan teman-teman yang lain merasa susah untuk memahami mata kuliah praktikum." - M.I.T

Situasi-situasi yang dihadapi tiap-tiap informan beragam, dari awal perkuliahan sampai perkuliahan saat ini yang dilakukan secara online. Kebanyakan anak kuliah sekarang mengeluhkan hal yang sama, yaitu banyaknya tugas kuliah. Hal itu juga yang dihadapi oleh mahasiswa perantau asal Papua - Papua Barat. Dalam menghadapi banyak hal dari awal perkuliahan sampai sekarang, tentu ada orang tua di belakangnya. Para informan menceritakan hubungan mereka dengan orang tua yang memampukan mereka berjuang di perantauan dan terus berjuang di perkuliahan online saat ini. Komunikasi para informan dengan orang tua atau keluarga mereka membantu mereka untuk mengatasi rasa lelah, memberi mereka semangat dan motivasi, serta menjadi tempat berbagi dan mengurangi stress.

Sebagian dari informan menyatakan bahwa saat di perantauan, mereka berkomunikasi dengan orang tua hampir setiap hari melalui telepon biasa, video-call, ataupun call melalui aplikasi WhatsApp. Komunikasi dengan orang tua ini sering kali untuk menanyakan kabar masing-masing anggota keluarga. Mahasiswa perantau cenderung menggunakan kesempatan tersebut untuk menceritakan keseharian mereka di perkuliahan dan lain sebagainya. Kesempatan berkomunikasi tersebut ternyata memberi semangat bagi mahasiswa kala berada di perantauan.

"Karna keluarga, terutama sa bapa hanya tau pake HP kayu atau Nokia jadi sa cuman komunikasi dengan bapa dong lewat telpon saja. Tapi itu su bersyukur skali karna bisa dengar keluarga dong punya suara, itu sih yang bikin sa semangat di rantau sana." - Y.S.W
"Saya hampir setiap hari berkomunikasi dengan orang tua saya. Jika jaringannya baik, kadang saya menggunakan WA namun kalau tidak saya hanya berkomunikasi melalui telepon biasa." - E.E.G

"Ya, selama diperantauan saya tetap berkomunikasi dengan orang tua atau keluarga saya. Biasanya kami berkomunikasi lewat WhatsApp, kadang SMS, tetapi lebih sering lewat telepon." - T.Y

Bagi para mahasiswa perantau - yang saat ini masih berada di perantauan ataupun sudah pulang ke kampung halaman dan tinggal dengan orang tua - komunikasi dengan orang tua tidak hanya memberi mereka semangat, tetapi juga membantu mengurangi stress atau perasaan tertekan saat perkuliahan. Kebanyakan mahasiswa merasa tertekan karena tugas yang banyak dan susah menurut mereka, tetapi melalui komunikasi dengan orang tua, seperti bercerita mengenai kesulitan yang dihadapi, mereka dapat menerima solusi dan juga bentuk support lainnya, seperti katakata motivasi, pelukan, atau bahkan hanya sekedar keberadaan dan kesediaan mendengarkan cerita mereka, hal tersebut sudah memberi semangat dan mengurangi perasaan tertekan.

"Ya, karena dengan pelukan mereka ketika saya mendapatkan nilai yang baik maupun buruk mereka selalu memberikan semangat motivasi dan nasehat. Kita samasama bisa mencari solusi bisa dan saling bertukar pikiran." - F.F.P.A

"Iya, saya sering menghubungi mereka saat saya merasa lelah terhadap dunia perkuliahaan dan setelah berbicara dengan mereka, saya seperti diingatkan bahwa ada orang-orang yang berharap saya bisa sukses dan menggapai mimpi-mimpi saya. Hal ini dapat membuat saya kembali bersemangat. Saat saya dapat menceritakan tentang padatnya perkuliahan dan tugas-tugas yang berat, saya akan merasa lebih legah dan mereka akan memberikan saran-saran kepada saya atau hanya sekedar menghibur saya." - M.P.K.W

"Seperti yang sa jawab di pertanyaan sebelumnya, sa tratau kenapa, tapi sa rasa sa kuliah sampe cape, kadang pikir sa trabisa buat ini, atau susah di matkul ini, tapi setiap terima telfon dari sa pu mama, itu kaya punya motivasi tersendiri untuk sa bangkit lagi, untuk sa yakinkan sa pu diri sendiri kalo sa sebenarnya bisa, sa cuma butuh usaha saja. Sekalipun jauh 
dari keluarga, tapi sa selalu rasa sa dekat dengan sa pu keluarga, karena tong selalu berkomunikasi. You know-lah, ada orang yang tidak terlalu dekat dengan dong pu keluarga, tapi buat sa, sa pu keluarga itu sa pu support system apapun keadaannya, untuk itu sekalipun tong di kota perantauan, lewat komunikasi saja su bantu tong skali untuk semangat kembali. Apalagi pelukan, pasti rasanya lebih berbeda. Saya merasa dengan adanya komunikasi dengan keluarga atau orang tua, kaya saya bisa berbagi cerita, berbagi cape maupun lelah meski cuma lewat telepon setidaknya mereka selalu ada di sana untuk mendengarkan cerita saya bahkan dalam hal yang tidak masuk akal pun, saya merasa selalu dipeluk saat sedang telepon atau berkomunikasi dengan orang tua atau keluarga saya." - T.Y

"Orang tua saya selalu memberikan semangat kepada saya entah mengenai perkuliahan atau hal lainnya, meskipun terkadang sebatas percakapan tetapi percakapan yang disampaikan orang tua saya merupakan kata-kata yang positif dan memberi dukungan untuk saya. Orang tua saya selalu memberikan dukungan dan selalu memberikan semangat sehingga mengurangi stress dalam perkuliahan dan orang tua saya selalu mengatakan untuk tetap berusaha karena orang tua saya tau kalau tidak hanya saya yang mengalaminya pasti ada beberapa temeanteman saya juga mengalaminya sehingga orang tua saya selalu memberikan support dan dukungan untuk mengurangi rasa stress perkuliahan." - M.I.T

"Tentu saja memberi semangat. Bapa dan mama selalu support dalam hal apapun mengenai perkuliahan. Kakak saya selalu merangkul dan memeluk saya, saat susah maupun senang. Jadi itu yang buat saya selalu bersemangat. Saya jarang menceritakan kesusahan tentang perkulihaan ke orang tua saya, tapi mama saya selalu tau saat saya susah. Mungkin dalam hal mengurangi stress lebih ke masak apa yang saya suka dan suruh saya jalanjalan keluar rumah. Saya cukup tertutup soal kesusahan." - Y.M.R

Selain pendapat para mahasiswa mengenai dampak komunikasi dengan keluarga, khususnya orang tua terhadap semangat dan stress yang mereka alami, peneliti juga menanyakan pendapat para mahasiswa mengenai komunikasi mereka dengan keluarga dapat memengaruhi kesehatan mental. Jawaban yang diberikan beragam, ada yang menganggap komunikasi mereka dengan orang tua memberi percaya diri dan semangat, memberi dampak baik, merasa legah, membantu berpikiran positif, memberikan dukungan psikis, mengobati. Bahkan, hubungan dengan keluarga dapat memberi dampak negatif pada kesehatan mental. Namun, ada pula yang mengatakan berkomunikasi dengan keluarga bukan caranya menghilangkan stress, karena sifat yang introvert.

"Saya adalah orang yang sangat pemalu dan tidak percaya diri. Ketika dikasih tugas kelompok saya sering kali takut dengan alasan dalam pikiran saya hasil yang saya kerjakan pasti salah atau tidak diterima. Tapi mama dan kakak serta adik saya, telfon dan memberikan semangat bahwa ko bisa percaya diri dan semangat. Akhirnya apa yang saya kerjakan mendapat nilai yang baik." - F.F.P.A

“... mereka turut membantu saya dalam mengurangi stress dan rasa cape yang saya rasakan sehingga hal ini tentu sangat baik bagi kesehatan mental saya. Berkomunikasi dengan mereka membantu saya untuk membuat diri saya merasa lebih baik dari sebelumnya, merasa lebih legah dan tidak terbebani sehingga hal ini tentu sangat membantu saya dalam menjaga kesehatan mental saya." - M.P.K.W

"Komunikasi dengan keluarga mempengaruhi kesehatan mental seseorang karena apabila kita sudah keluar dan tidak bersama-sama dengan orang tua secara tidak langsung kita harus melalukan segala sesuatu sendiri. Dan apabila komunikasi kita tidak baik dengan orang tua, dan orang tua kita juga tidak membangun komunikasi yang baik dengan kita, cenderung kita akan selalu berpikiran negatif. Dan hal ini akan sangat berpengaruh pada mental seseorang apalagi yang sedang berada di perantauan." - E.E.G

"Sa tratau mo mulai dari mana, tapi sejauh sa di perantauan ini, sa pu keluarga selalu bisa jadi sa pu tempat untuk pulang, tempat sa bisa lepas segala hal yang sa trabisa ungkapkan ke org lain, tempat sa berkeluh kesah, berbagi sa pu rasa cape, stress, pikiran, sa pu keluarga ada disana untuk support sa dan rangkul sa kas semangat untuk kuat lewati masa-masa itu, dan sa rasa itu berguna skali untuk sa pu kesehatan mental, karena ada sa pu 
org tua dan keluarga dong disana yang jadi sa pu support system. Sa pikir, banyak org mungkin lebih pilih memendam itu sendiri, tapi sa rasa itu tidak baik juga untuk dong pu kesehatan mental, dimana dong butuh orang lain untuk berbagi dan sa bersyukur sa bisa berbagi banyak hal dengan sa pu orang tua maupun sa pu keluarga." - T.Y

"Komunikasi saya dengan keluarga sejauh ini baik-baik saja, namun beberapa kali kami bertengkar karena 1 dan lain hal sehingga membuat kesehatan mental saya di tanah rantau sedikit terganggu, hingga saya tidak makan dan lebih mengurung diri sendiri di kost." - N.K.S

"Ketika saya mengalami suatu hal yang membuat saya benar-benar tidak kuat, satu hal saja yang akan saya lakukan yaitu saya pasti selalu menghubungi kedua orang tua saya, terkadang saya ingin kedua orang tua saya mendengarkan apa yang saya ceritakan tidak hanya salah satu dari mereka. Karena dengan kehadiran mereka untuk mendengarkan apa yang saya ceritakan bisa membuat saya merasa lebih baik dan lebih tenang." - M.I.T

"Saya hanya perlu didengar jadi kalo saya sudah tau bahwa cerita saya tidak akan didengarkan, saya tidak akan cerita, mental down sebelum cerita. Sa introvert. Sa copping stress dengan diskusi dan jalan-jalan, jarang cerita ke keluarga. Mungkin cuma ke kakak (sepupu) yang tadi sa sebutkan dan mungkin lebih ke tindakan." - Y.M.W

Sifat terbuka dan sikap mau mendengarkan dalam komunikasi memberi dampak positif bagi mental mahasiswa. Terlihat dari hasil wawancara di atas, komunikasi merupakan hal yang penting dan juga sebuah kebutuhan manusia. Dalam prosesnya agar komunikasi itu efektif, perlu keterbukaan antara kedua belah pihak yang berkomunikasi. Sifat tertutup pada salah satu pihak dalam komunikasi akan menghambat atau menutup jalannya komunikasi, hal ini juga dapat menimbulkan permasalahan. Sebaliknya, keterbukaan dalam komunikasi membantu komunikan untuk terus melanjutkan proses komunikasi.

Keterbukaan dalam komuniaksi juga menjadi kesempatan bagi komunikan untuk menyampaikan yang sebenarnya dan mendapat umpan balik yang mungkin diinginkan, yang mana dapat membantu kesehatan mental. Emosi yang dipendam tidak memberikan solusi, sehingga komunikasi menjadi sarana untuk menyuarakan emosi kita, isi hati, ataupun pikiran, sehingga mengurangi tekanan atau stress. Sama halnya dengan yang terjadi dengan para mahasiswa perantau di atas, keterbukaan mereka kepada orang tua akan situasi mereka, baik yang mereka hadapi di perkuliahan maupun di kehidupan seharihari, serta keterbukaan orang tua untuk mau mendengar memberi dampak positif bagi keadaan mental para mahasiswa. Para mahasiswa yang terbuka cenderung merasa lebih legah dan mendapat motivasi. Setelah menyuarakan isi hati dan mendapat respon dari orang tua, perasaan tertekan karena perkuliahan, tugas, ataupun hal lainnya menjadi hilang.

Inilah alasan komunikasi interpersonal dalam keluarga itu penting untuk kesehatan mental, karena melaluinya anggota keluarga bisa saling menguatkan, mendorong atau memberi semangat, meringankan tekanan dan stress. Setiap manusia tidak dapat hidup sendiri, selalu memerlukan orang lain untuk melakukan berbagai hal bersama, ataupun sekedar untuk berbagi cerita atau mendengar cerita. Pada suatu kondisi, manusia dapat merasakan perasaan tertekan atau stress, dan terkadang perlu menyuarakan isi hati atau perlu seseorang yang dapat mendukung dan memberi motivasi.

Keluarga adalah salah satu yang terdekat. Keberadaan anggota keluarga, secara tidak disadari sangat berdampak pada kesehatan mental seseorang. Kata-kata, perlakuan, tindakan dari anggota keluarga dapat memberi dampak pada perasaan dan keadaan mental seseorang. Oleh karena itu, komunikasi dalam keluarga dapat menjadi sarana untuk mengatasi kesehatan mental seseorang. Komunikasi banyak banyak bentuknya, verbal atau nonverbal, yang intinya sama-sama menyampaikan suatu pesan, menerima pesan, dan memberi umpan balik terhadap pesan yang diterima. Dari wawancara di atas, komunikasi para mahasiswa dengan orang tua selalu memberi semangat, dorongan, mengurangi stress. Sebaliknya, suatu masalah dengan orang tua dapat memberi dampak negatif. Kesempatan untuk berbicara dengan orang tua sudah menjadi kelegaan bagi sebagian besar mahasiswa, apalagi ketika mendapat umpan balik berupa nasehat, kata-kata positif, dan berupa tindakan seperti pelukan, bahkan 
masakan dari ibu dapat memberi perasaan nyaman.

\section{SIMPULAN}

Keberadaan keluarga bagi para mahasiswa rantau di atas menunjukkan bahwa keluarga ambil andil dalam suasana hati yang dirasakan seorang anggota keluarga. Cenderung masalah yang dihadapi tidak dapat semuanya dikatakan kepada keluarga, tetapi akan selalu ada hal yang ingin diceritakan ke pada orang tua atau anggota keluarga yang lain. Setiap cerita para mahasiswa di atas pada orang tua mereka menunjukkan keterbukaan dalam komunikasi membantu mahasiswa merasa lebih lega dari perasaan tertekan. Umpan balik yang diberikan orang tua, seperti kesediaan untuk mendengar cerita anak, memberi nasihat ataupun kata-kata semangat, pada akhirnya memberi motivasi bagi para mahasiswa untuk menjalani perkuliahan di tengah pandemi saat ini. Bahkan percakapan ringan antara anggota keluarga membantu mahasiswa merasa lebih ringan saat stress dengan tugas kuliah, kurang percaya diri, rindu rumah (homesick), dan lain sebagainya.

\section{DAFTAR PUSTAKA}

Bonaria, J. (2021). Gangguan Kesehatan Mental yang Disebabkan Oleh Pendidikan Jarak Jauh Terhadap Mahasiswa Selama Pandemi Covid19. Jurnal Medika Hutama, 03(01), 15121518.

https://jurnalmedikahutama.com/index.php /JMH/article/view/307/209

Cahyanti, A. (2020). Peran Keluarga dalam Membentuk Kesehatan Mental Remaja di Kelurahan Yosorejo 21 A Metro Timur. InstitustAgama Islam (IAIN) Metro.

Creswell, J. W., \& Creswell, J. D. (2018). Research Design: Qualitative, Quantitative, and Mixed Methods Approaches (Fifth Edit). SAGE.

Djayadin, C., \& Munastiwi, E. (2020). Pola Komunikasi Keluarga Terhadap Kesehatan Mental Anak Di Tengah Pandemi Covid-19. Raudhatul Athfal: Jurnal Pendidikan Islam Anak Usia Dini, 4(2), 160-180.

Hasibuan, E. J. (2011). Peranan Komunikasi Dalam Keluarga Terhadap Pembentukan Jati Diri Remaja. Perspektif, 4(2), 141-153. https://doi.org/10.31289/perspektif.v1i2.9
Kiling, I. Y., Mita, T. L., Takoy, M., Wila, F. A., Seda, E. K., \& Bani, T. (2021). Emotion-focused Coping sebagai Strategi Koping Mahasiswa selama Pembelajaran Daring di masa Pandemi. PROSIDING: Temu Ilmiah Nasional, 1, 309320.

Koraag, N., Sondakh, M., \& Tangkudung, J. P. M. (2021). Peranan Komunikasi Antarpribadi Orangtua Dalam Mengantisipasi Tindak Kriminal Anak Remaja di Desa Pineleng 1. ACTA DIURNA KOMUNIKASI, 3(3), 1-11. https://ejournal.unsrat.ac.id/index.php/acta diurnakomunikasi/article/view/34913

Lestari, S., \& Risqi, P. M. (2021). Representasi Kesehatan Mental Siswa pada Masa Pandemic Covid-19. PROSIDING: Temu Ilmiah Nasional, 1, 45-53.

Lubis, H., Ramadhani, A., \& Rasyid, M. (2021). Stres Akademik Mahasiswa dalam Melaksanakan Kuliah Daring Selama Masa Pandemi Covid 19. 10(1), 31-39. https://doi.org/10.30872/psikostudia

Nuzuli, A. K. (2020). KOMUNIKASI ORANG TUA DAN TINGKAT STRES MAHASISWA PERANTAUAN PADA LARANGAN MUDIK COVID-19. 10(2017), 242-260. https://doi.org/10.35905/komunida.v7i2.ht tp

ROKOM. (2019). Perlu Kepedulian untuk Kendalikan Masalah Kesehatan Jiwa. Kementerian Kesehatan RI; Redaksi Sehat Negeriku. https://www.kemkes.go.id/article/view/19 093000001/penyakit-jantung-penyebabkematian-terbanyak-ke-2-di-indonesia.html

Sampe, N., Tinggi, S., Kristen, A., Toraja, N., Toraja, T., \& Selatan, S. (2019). Komunikasi Interpersonal Keluarga Kristen Memasuki Era 4.0. Jurnal Teologi Dan Pendidikan Kristen Kontekstual, 2(1), 72-82. https://www.jurnalbia.com/index.php/bia/ article/view/84

Saskara, I. P. A., \& Ulio. (2020). PERAN KOMUNIKASI KELUARGA DALAM MENGATASI "TOXIC PARENTS" BAGI KESEHATAN MENTAL ANAK. Pratama Widya: Jurnal Pendidikan Anak Usia Dini, 5(2), 125-134.

Tatang, S. (2016). Dinamika Komunikasi. CV Pustaka Setia.

UNICEF. (2021). Dampak COVID-19 terhadap rendahnya kesehatan mental anak-anak dan pemuda hanyalah 'puncak gunung es' UNICEF

UNICEF. https://www.unicef.org/indonesia/id/press -releases/dampak-covid-19-terhadaprendahnya-kesehatan-mental-anak-anakdan-pemuda-hanyalah. 